IZA DP No. 7613

Female-Led Firms: Performance and Risk Attitudes

Pierpaolo Parrotta

Nina Smith

September 2013

Forschungsinstitut zur Zukunft der Arbeit Institute for the Study of Labor 


\title{
Female-Led Firms: Performance and Risk Attitudes
}

\author{
Pierpaolo Parrotta \\ University of Lausanne \\ and Aarhus University
}

Nina Smith

Aarhus University

and IZA

Discussion Paper No. 7613
September 2013

IZA

P.O. Box 7240

53072 Bonn

Germany

Phone: +49-228-3894-0

Fax: +49-228-3894-180

E-mail: iza@iza.org

Any opinions expressed here are those of the author(s) and not those of IZA. Research published in this series may include views on policy, but the institute itself takes no institutional policy positions. The IZA research network is committed to the IZA Guiding Principles of Research Integrity.

The Institute for the Study of Labor (IZA) in Bonn is a local and virtual international research center and a place of communication between science, politics and business. IZA is an independent nonprofit organization supported by Deutsche Post Foundation. The center is associated with the University of Bonn and offers a stimulating research environment through its international network, workshops and conferences, data service, project support, research visits and doctoral program. IZA engages in (i) original and internationally competitive research in all fields of labor economics, (ii) development of policy concepts, and (iii) dissemination of research results and concepts to the interested public.

IZA Discussion Papers often represent preliminary work and are circulated to encourage discussion. Citation of such a paper should account for its provisional character. A revised version may be available directly from the author. 
IZA Discussion Paper No. 7613

September 2013

\section{ABSTRACT}

\section{Female-Led Firms: Performance and Risk Attitudes}

This paper investigates the relationship between gender of the CEO and composition of the board of directors (female chairman and share of women in the boardroom) and firm's risk attitudes measured as variability in four firm outcome variables (investments, profits, return to equity, and sales). Using a merged employer-employee panel sample of Danish companies with more than 50 employees, we find extensive evidence of a negative association between female CEO and firm's risk attitudes. This finding might be consistent with the theoretical assumption according to which women typically present a substantially higher risk aversion profile and put more effort in monitoring firm activities than men in the financial matter domains. A number of robustness checks corroborate and better explain our main findings.

JEL Classification: $\quad$ G34, J16, L25

Keywords: female CEO, risk aversion, firm performance

Corresponding author:

Pierpaolo Parrotta

University of Lausanne

Department of Economics

$\mathrm{CH}-1015$ Lausanne

Switzerland

E-mail: pierpaolo.parrotta@unil.ch

\footnotetext{
* We thank Rafael Lalive for his valuable comments and suggestions. Pierpaolo Parrotta and Nina Smith gratefully acknowledge the financial support from the Calsberg Foundation. Pierpaolo Parrotta also acknowledges the financial support from the Swiss National Centres of Competence in Research LIVES.
} 


\section{Introduction}

A number of recent studies have focussed on gender differences in preferences and behavior. Many of these studies find that women tend to be more risk averse than men with respect to participating in a risky gamble or risky behavior in general. If women tend to be more risk averse than their male peers, companies which are led by females, either by having a female CEO, a female chairman or having a large proportion of women in the boardroom, may experience different economic outcomes. Risk aversion in decision making may affect the level of performance, growth rates or investment strategies but risk averse behavior may also have an impact on firm volatility with respect to these outcomes and performance. If women are more risk averse than men in their decision making, female-led companies are expected to experience less volatility in their economic outcomes. A number of empirical studies have analyzed the relationship between firm performance and gender diversity in the boardroom. The results from these studies are mixed. However, when concentrating on differences in risk preferences, it is expected that a high risk aversion in decision making will imply a lower volatility profit and other performance measures. Thus, if women are more risk averse decision makers, it should be expected that female-led firms have a more stable performance but at the expense of the absolute performance level.

This paper presents empirical evidence on potential effects of female-led companies with respect to both the level of economic outcomes measured as investments, profits, return on equity, and sales and with respect to variability over time in these outcomes. The contribution of this paper is to study the relation between female top managers and firm behavior with respect to volatility in key outcome variables based on field data, i.e. non-experimental data. While most of the existing evidence on gender differences stems from laboratory data typically using the input from students or relatively young people representing a broad section of the population, this study is based on real-life data of companies and studies the selected sample of women who reach top positions in companies and who may behave very differently from a representative sample of young female students. Our results indicate that also this subsample of female managers differs compared to their male peers. When controlling for a number of observed characteristics and for time constant unobserved firm heterogeneity, our findings are that female-led firms tend to be less volatile over time with respect to investments, return on equity, profits and sales compared to male-led companies. The most important difference is found for firms with a female CEO compared to firms with a male CEO, while the gender of the chairman of the board and the board composition in general seem to be less significant with respect to volatility in economic outcomes.

The structure of the remainder of this paper is as follows: First, literature background is presented in Section 2, Sections 3-4 describe the data and the estimation strategy, Section 5 discusses the main results, 
Section 6 reports alternative robustness checks, and Section 7 concludes.

\section{Literature background and hypotheses}

In this section we report findings from two different fields of studies concerning the testing of gender differences in risk preferences and the link between gender diversity on company boards and firm performance, respectively. In fact, we combine these two fields in order to describe how the presence of female directors might be associated with a substantially lower variability in firm outcomes and performance.

A summary of the experimental literature testing gender differences in risk preferences is discussed by Croson and Gneezy (2009) and Eckel and Grossman (2008). Experimental studies typically compare the behavior of women and men (college students in most of cases) in a risky gamble that either rely on hypothetical choices or involve real but often small stakes (Bertrand, 2011). Among the abstract gamble experiments, some works present both the gain and loss domains whereas others fall in the gain domain (gamble with no negative payoff amounts) exclusively. For instance, Levin et al. (1988) ask 110 college students to indicate whether or not they are willing to take each of 18 different gambles, which differ in initial investment, amount to be won, level of probability, and gain/loss framing. They find that men have higher reported take-up rates than women. Hartog et al. (2002) elicit hypothetical certainty equivalents for a series of high-stakes lotteries. Thus, they estimate the risk aversion parameter of a utility function for a large sample of individuals and find significant and substantial gender differences in risk aversion: from 10 to 30 percent larger for women. Eckel and Grossman (2002a) ask 148 college students to choose among five alternative gambles with two equally probable payoffs but differing in expected return and variance. They report that men on average choose riskier gambles with higher expected payoffs. Further, Eckel and Grossman (2002b) provide evidence that women's higher risk aversion hold both in the loss and in the gain domain.

However, whereas the laboratory experiments may lead to results that generalize to the high-stakes settings is still an open question, several studies in the domain of financial risk find evidence of strong gender differences as found in lab experiments. For example, analyzing the contribution pension allocation decisions of 20,000 management employees of a large U.S. employer, Bajtelsmit and VanDerhei (1997) find that women, compared to men, hold a significantly greater share of their account balances in relatively lowrisk fixed income investments and a significantly smaller share in higher-risk employer stock. Using data from the 1989 Survey of Consumer Finances, Jianakoplos and Bernasek (1998) report that single women hold smaller proportions of their wealth in risky assets compared to single men. Similar conclusions are drawn in Sunden and Surette (1998). Benefiting from a US national survey of close to 2,000 mutual fund investors, Dwyer et al. (2002) find that women exhibit less risk-taking than men in their most recent, largest, 
and riskiest investment decisions even when controlling for knowledge of financial markets and investment. Interestingly, Dohmen et al. (2011), using a large representative survey and a complementary experiment conducted with a representative subject pool, find that women are less willing to take risks especially in car driving and financial matters: the gender effect corresponds to about a quarter of a standard deviation reduction in the willingness to take risks.

Summing up, Eckel and Grossman (2008, p. 1071) conclude in their survey of field and lab studies of gender differences in risk preferences that 'the findings from field studies conclude that women are more risk averse than men. The findings of laboratory experiments are, however, somewhat less conclusive'. One of the reasons for the differences between field and laboratory studies may be that both types of studies often do not control for other demographic factors than gender, wealth, income, and other context related factors which may affect decision making.

The second strand of literature which this study builds on concerns the relationship between women in the boardroom and firm performance. The research on this topic has reported quite mixed results. ${ }^{1}$ Drawing information on 200 Fortune-listed firms in 1993, Shrader et al. (1997) find evidence of a negative association between several financial indicators (ROE, ROA, ROI and ROS) ${ }^{2}$ and the share of women on boards. Interestingly, such an association flips sign when it is regressed on the share of women in managerial positions, estimates are however not always statistically significant. A similar study by Erhardt et al. (2003) uses data from 112 Fortune firms observed for the period 1993-1998, and analyzes the link between board diversity, in terms of either ethnicity or gender, and two relevant measures of firm performance like ROA and ROI. They find that none of the two financial indicators are significantly related to gender diversity on board. Similar conclusions are drawn by Kochan et al. (2003), which also find no support for a positive link between gender diversity in management and firm performance for large US companies. Using information from a larger sample (797 Fortune 1000 firms), Carter et al. (2003) report a significantly positive relationship between the percentage of women and minorities on boards of directors and firm value, measured as Tobin's $\mathrm{Q}$ and ROA. A more recent study by Adams and Ferreira (2009) shows that a positive correlation between performance and board diversity, compatible with studies by Catalyst (2003, 2007) and Carter et al. (2003), is found when firm fixed effects are not accounted for. However, the inclusion of these unobserved timeinvariant firm characteristics flips the sign of the estimates, suggesting that firm specific omitted variables are positively correlated with the error term. No significant or even negative correlations between gender diversity on boards and firms performance have been found in studies conducted in the European context. For instance, Du Rietz and Henrekson (2000) report no significant results when controlling for firm size and

\footnotetext{
${ }^{1}$ See Terjesen et al. (2009) for a survey of these studies.

${ }^{2}$ Returns on Equity, Returns on Assets, Returns on Investments, and Returns on Sales, respectively.
} 
sectors for a sample of Swedish firms. Smith et al. (2006), anticipating the Adams and Ferreira critique, find no significant effects after controlling for unobserved firm-specific factors in a panel study of the 2,500 biggest Danish firms during the period 1993-2001. Consistent with the latter study, Rose (2007) finds no significant correlations on a sample of Danish firms listed on the national stock market during 1998-2001. Bøhren and Strøm (2007) report a significantly negative relationship between the proportion of women on boards of directors and firm performance measured by Tobin's Q in Norwegian listed non-financial firms in 1989-2002. A number of studies have analyzed the introduction of a mandatory 40 percent female quota on boards of Norwegian firms and also for this specific 'experiment' the empirical evidence is mixed, see Smith (2013). One of the problems in identifying the impact of the Norwegian gender quota on boards of directors is the fact that Norwegian companies might have endogenously chosen the timing of adjustment, which could be driven by previous and expected firm performance, and hence their identification strategy might be not valid (Ferreira, 2010).

Scholars have proposed a potential explanation for the negative association between gender diversity at the board level and firm performance that is the glass cliff effect: women might be appointed as directors of poor performing companies in periods of decline (Ryan and Haslam, 2005). As a consequence, it would imply that corporate performance could influence the proportion of women on boards. Although, it surely represents an intriguing theoretical prediction, several studies (Ryan and Haslam, 2005; Adams et al., 2008) do not find evidence supporting such a phenomenon.

Interestingly, Adams and Ferreira (2009) shed light on an aspect that has been just marginally investigated in the literature (e.g., Kesner, 1988; Bilimoria and Piderit, 1994), which refers to the fact that women are typically more under-represented in executive and nominating committees but not in audit committees. The authors argue and provide evidence that female directors seem to be tougher monitors (more independent from managers) than their male colleagues, and that an excessive emphasis on monitoring could harm performance in firms that are otherwise well governed.

This emphasis on monitoring may also have the effect that there are less 'shocks' to different financial variables of the company, that female-led companies tend to have a more stable development of key financial parameters. To the best of our knowledge, no earlier studies have investigated the relationship between female-led companies (a female CEO or the presence of women in the boardroom) and the variability in firm performance, which is the aim of the present article. ${ }^{3}$ In doing so, we combine the empirically supported theoretical prediction dealing with the higher risk aversion profile of women and their strong focus on mon-

\footnotetext{
${ }^{3}$ Of course, we do not include the stock volatility among the indicators of firm performance because it might be caused by different factors and likely related to the expected rather than the actual performance. A number of studies (e.g., Ferreira, 2002; Farrell and Hersch, 2005; Hillman et al., 2007; and Adams and Ferreira, 2009) report a positive relationship between board diversity and stock return volatility.
} 
itoring firm activities. Specifically, we investigate whether and how the presence of a female CEO, female chairman, the interaction between these variables, and the proportion of women on boards are associated with the level and variability in firm performance.

\section{Data}

In this section we describe the main features of our data set and report a descriptive analysis supporting a prima facie evidence for the purposes of our study.

\subsection{Sample selection and variable definitions}

Our data set is an unbalanced panel of all privately owned or listed Danish firms with at least 50 employees observed during the period 1997-2007. It contains detailed information on several annual firm characteristics retrieved from the Danish register data and supplemented with variables from Experian, a private Danish data account register which among other things has information on the names of all board members of Danish company boards and their position within the board (chairman, staff or non-staff member etc.). Further, Experian has information on economic performance and other relevant data based on annual company reports to the authorities. Register data are collected by Statistics Denmark and include an extensive amount of information both at the individual and the firm levels, which can be merged by using an employer-employee link variable. Statistics Denmark has also merged the firm information from Experian with the register information for the firms included in this sample.

The merged data set we use informs on the gender of the $\mathrm{CEO}^{4}$ and/or the chairman of the board of directors, the proportion of women on the board; the percentage of workers with different educational levels, with different occupations, being 1st and 2nd generation immigrants; shares of women (scaled to the total number of women within the firm) with different educational levels, with different occupations, being 1st and 2nd generation immigrants; firm size, industry affiliation; firm export, import, new established status. Our four outcome variables are (i) firm net investments, (ii) gross profits (net sales minus input expenses, i.e. costs of goods sold), (iii) return on equity $(\mathrm{ROE}=$ net profits relative to net capital), and (iv) total sales.

\footnotetext{
${ }^{4}$ The exact definition using Statistics Denmark's 'DISCO-codes' is: CEO=Executive director (RAS-DISCO code 121, 1210). The registration of the DISCO codes in the administrative registers has been improved during the observation period. In order to remove outliers or errors in the DISCO codes, we restrict the CEO group to individuals who are observed with annual earnings in top 10 of the firm. The definition of the CEO and the sample selection in this study are different from the sample in Smith et al. (2013), mainly because we do not include companies with less than 50 employees in the present study when defining the group of potential top executives.
} 


\subsection{Descriptive analysis}

Table 1 reports means and standard deviations of the main variables used in the analysis over the period 1997-2007. In fact, we alternatively use 4 different samples of firms because information on the four outcome variables is missing in some cases and the use of a common sample would have implied a severe drop in the total number of observations.

We have 4,713 observations referring to 1,947 firms for the outcome variable investment, 5,023 observations (1,996 firms) for profits, 4,563 observations (1,918 firms) for ROE, and 6,779 observations (2,409 firms) for sales that represents the largest sample. Although sample sizes differ among the outcome variables, descriptive statistics are fairly similar even for comparison between firms with a female $\mathrm{CEO} /$ female chairman and full sample values. Not surprisingly, we find that the average numerical growth in investments is larger than the one referring to the other firm outcome variables. This is in fact due to the usual lumpiness in the firm capital adjustment, which is particularly costly.

We typically observe a female $\mathrm{CEO}$ in about $0.7 \%$ and a female chairman in slightly more than 2.5 percent of the cases, whereas it is very rare (between 0.04 percent and 0.07 percent) to have both a female CEO and a female chairman in the firm boardroom. ${ }^{5}$ On average women represent 11 percent of the total number of board directors and a third of the firm workforce. About 5 percent and 8 percent of female employees achieved a tertiary education and hold a high level position within the company, respectively. In line with the aggregate statistics on the Danish firm population, more than 75 percent ( 83 percent) of enterprises are involved in exporting (importing) activities but just around 4 percent are listed on the national stock exchange market. More than half of the observed companies present a workforce between 100 and 500 employees, 16 percent employ at least 500 individuals, and the rest of the sample (34 percent) is composed of small firms (between 50 and 100). The comparison of female CEO and female chairman sub-samples with the full sample indicates that female-led companies tend to have more female employees and to be less international with respect to importing and exporting (however, not all of these differences are significant differences given the size of the standard errors). Further, there is a difference with respect to size of the company (number of employees) between companies led by a female CEO and companies led by a female chairman on the board of directors: The latter companies tend to be smaller, while companies with a female CEO tend to be larger than the full sample.

Figures 1 and 2 focus more explicitly on what happens to companies when a female CEO or a female chairman takes over from a male $\mathrm{CEO}$ or a male chairman. Both figures refer to the sample of firms that experience a change in the $\mathrm{CEO}$ gender (a male CEO is replaced by a female CEO), have on the horizontal

\footnotetext{
${ }^{5}$ Formally, the CEO is not considered a member of the board of directors in Denmark which has a two-tier organization in companies. The CEO participates in board meetings but is not formally a board member.
} 
axis the year to or from the change in CEO gender occurs (the year of this change is indicated by a dashed line). On the vertical axis, the observed mean values (dots) and a superimposed quadratic fit (lines) in the outcome variable are shown. Whereas it is questionable whether we observe a generally better trend in the firm performance, a lower degree of variability seems to characterize the pattern of the outcome variable in case of a female CEO. Although, the reason behind the change in the CEO position is not controlled for in Figures 1 and 2, the results reported in both figures might represent a preliminary evidence of a statistical association between the CEO gender and the firm's risk attitudes.

\section{Empirical strategy}

To investigate the relationship between our variables of interest (whether there is a female CEO, a female chairman, the interaction between these two, and the share of women on board of directors) and each of the four outcome variables (investments, profits, ROE, and sales) both in levels and numerical growth rates, we implement a linear model as it eases the interpretation of estimates and addressing some econometric issues like omitted variable bias. Specifically, we estimate the following model:

$$
\begin{gathered}
y_{i t}=\alpha+\beta F_{-} C E O_{i t}+\gamma F_{-} C_{\text {airman }}+\delta F_{-} C E O_{-} C h a i r m a n_{i t}+\rho S_{\text {Share }} F_{-} \text {Board }_{i t} \\
+x_{i t}^{\prime} \beta+z_{i t}^{\prime} \omega+\eta_{i t}+u_{i}+v_{i t}
\end{gathered}
$$

where $F_{-} C E O, F_{-}$Chairman, $F_{-} C E O_{-}$Chairman are indicators taking the value of 1 in firms with a female CEO, a female chairman of the board of directors, and both a female CEO and female chairman, respectively. The dependent variable $y_{i t}$ represents either the absolute level or the numerical value of the annual relative change in each of the four outcome variables (investments, profits, return on equity, and sales). Thus, each dependent variable is regressed on our variables of interest, a set of standard controls $x_{i t}$ (dummies for year, industry and firm size) and firm characteristics $z_{i t}$ (shares of women among all employees in the firm, shares of women with different educational levels, shares of women with different occupations, shares of women being 1st and 2nd generation immigrants, shares of total workers with different educational levels, shares of workers with different occupations, share of workers being 1st and 2nd generation immigrants, export rate, import rate, and an indicator for being a newly established firm. Further we add an indicator variable for the year of change in chairman gender and CEO gender (from male to female in both cases) $\eta_{i t}$. 
This indicator controls for the fact that the year of change for gender of the chairman or CEO by definition is a mixed year with respect to gender of the CEO or chairman. The error term is composed of a time-invariant firm effect $u_{i}$ and a time-varying (supposed to be purely idiosyncratic) term $v_{i t}$. As the former is likely to be correlated with our variable of interest, we follow the standard FE approach and therefore focus on the within-firm effect. Further, we include an indicator, $\eta_{i t}$, taking the value of 1 for the (eventual) year of change in CEO and chairman gender in our specifications. Thus, our FE approach provides DID estimates of the parameters of interest.

However, endogeneity issues like reverse causality or correlation between chairman gender and timevarying firm fixed effects may still arise in our FE estimates. Unfortunately, we do not have valid instruments in the data set to deal with the potential endogeneity of our variables of interest. Therefore, we prefer to apply a FE approach since it is well known that the choice of less valid instruments can lead to any kind of result (Ferreira, 2010). Thus, our results cannot be considered causal effects of female-led companies. However, we try to cope with potential endogeneity issues and give evidence for the robustness of our results by performing alternative endogeneity checks.

\section{Results}

Our main results are reported in Tables 2 - 5. Each table refers to an outcome variable and is divided into two parts, on the left-hand side the dependent variable is taken in levels whereas on the right-hand side in numerical growth rates. We present both OLS and FE (firm fixed effect) regressions without controls, with standard controls and with the full set of covariates.

Our favorite specifications are the FE ones as we can remove the influence of firm time-invariant heterogeneity and thus compute within-estimates on our variables of interests: $F_{-} C E O, F_{-}$Chairman, the interaction between these two variables, $F_{-} C E O \_C h a i r m a n$, and the proportion of women on the board of directors, Share_F_Board. We also report parameters on the share of women in high level positions and the share of women with a high education.

The main results reported in Table 2 inform us that although none of our variables of interest significantly matter for the absolute level of investments, the presence of a female CEO is associated with a drastic reduction in the volatility of this financial variable (defined as the numerical value of the annual growth rate of investments). The estimate on $F_{-} C E O$ in our preferred specification (last column) is highly significant and the estimated reduction in the variability of investments is about 56 percent. There are no significant coefficients for the other variables of interest. Specifically, the gender of the chairman of the board of directors does not seem to matter for neither investment levels or volatility in investments. 
Table 3 shows findings for the dependent variable annual profits. In the left part of the table, the OLS specifications for some of the variables of interest carry significant estimates. For instance, the simple OLS estimates of share of women on board of directors, Share_F_Board, are significantly positive as found in other studies of the simple correlation of women on board of directors. But none of the results are robust to the inclusions of controls in the FE specifications in column 6. Instead, looking at the right part of the table, we observe again a robust and significantly negative estimate on $F_{-} C E O$. It implies that on average replacing a man with a woman in the CEO position is associated with a substantially (10 percent) lower variability in profits.

Interesting insights are provided also by results reported in Table 4. Here the dependent variable is return on equity, ROE, one of the main indicators for investors and shareholders. We find that female CEOs are significantly associated with considerably lower ROE: about 18 percent less than in the counterfactual case in our reference specification. Female CEOs not only seem to be inclined to "reward" shareholders more parsimoniously but also tend to do that in a more stable way. In fact, the estimate on $F_{-} C E O$ is highly significant and negative: the volatility in ROE is 14 percent lower when a woman replaces a man at the CEO level. A further reduction is found also with a higher share of women on board of directors. Specifically, a (within-firm) standard deviation increase in such a share (0.061) is associated with a reduction of $\left(-0.356^{*} 0.061=\right) 2.2$ percent in ROE numerical growth rates.

Table 5 informs us on the relationship between our key variables and the dynamics in sales. Relying on our favorite specifications (columns 6 an 12), we find that the share of women in the boardroom is negatively associated with the firm performance in terms of sales: a (within-firm) standard deviation increase in the proportion of female members of the board (0.072) is related to a reduction in output growth by about $\left(-0.027^{*} 0.072=\right) 0.2$ percent. Further, as for the volatility of the other financial indicators, it emerges that replacing a man with a woman at the CEO seat is negatively correlated with the variability of sales over time (but not the absolute level of sales), the reduction is about 6 percent.

Summing up, the overall findings in this section do not indicate any significant relationship between gender diversity at the managerial level and economic performance of the firm. However, we find a fairly robust empirical evidence that female-led companies tend to be less volatile with respect to the considered economic outcomes. All in all, these findings are in line with the theoretical predictions according to which women typically present higher risk aversion profiles and have stronger emphasis on monitoring firm performance.

\section{Robustness checks}

In this section we discuss how sensitive our main results are to some robustness checks. Firstly, Table 6 
reports a number of checks testing the endogeneity arising from possible anticipation effects. All columns refer to FE regressions in which the key parameters are on the 1-year leads of our variables of interest (female-led variables), see for instance the discussion of this endogeneity test in Angrist and Pischke (2009, p. 237). It clearly emerges that none of such variables carries significant effects, dispelling this way part of the eventual endogeneity concerns affecting our estimates.

Secondly, we run our most complete FE regression for each outcome variable in numerical growth rates by firm size (below versus above 100 employees i.e. 'small' versus 'large'), by industrial sector (service versus non-service), by firm export status (export versus non-export), and distinguishing between companies listed on the national stock exchange and non-listed ones. Results from these robustness checks are reported in Table 7.

The variability in investment is characterized by a negative association with the change in CEO gender also for the subgroups in Table 7. This finding is robust to all checks except for 'export' and 'listed' that show insignificant parameters (however, in some of these subgroups, the number of observations is small, and thus, the estimates are imprecise). The reduction in the numerical growth rates of investment is also related to the change in the chairman gender for non-exporting firms.

Concerning the variability of firm profits, we find evidence of a negative correlation with $F \_C E O$ for enterprises with more than 100 employees, operating in a non-service industry, and not involved in exporting activities or not listed. Interestingly, the replacement of a man with a woman in the chairman position is associated with a lower (higher) variability of profits for small (non-exporting) firms. Further, the interaction between $F_{-} C E O$ and $F \_C h a i r m a n$ presents an extremely negative link with the fluctuations in profitability for large companies.

Moving to the ROE indicator, it also emerges that the robustness estimates support the main findings. The negative relationship between $F_{-} C E O$ and the ROE variability is confirmed in almost all cases though it is statistically significant only for firms in Large, Service and Export subsamples. A larger share of women on boards seems to be correlated with a lower fluctuation in $\mathrm{ROE}$ as in the main results, for companies that are not listed or exporting or operating in non-service industries. Finally, robustness checks for variability in 'sales' are in line with main results for 'large', 'service', 'non-export' and 'non-listed' subsamples. Again all variables representing female-led firms have either significantly negative or insignificant coefficients for all sub-groups of companies.

Overall, these robustness checks support the hypotheses developed in Section 2, corroborating and better explaining our main results. Specifically, we find that the negative association between $F \_C E O$ and the variability in firm outcomes is particularly robust for non-exporting or non-listed firms. This finding might suggest that control and monitoring activities in such categories of firms seem less effective when a man holds 
the CEO position and that the need for a tougher female-led governance might be present!

\section{Conclusions}

In this paper, we provide empirical evidence on potential effects of female-led companies with respect to both performance and risk attitudes. Specifically, using data on privately owned or listed Danish firms with at least 50 employees observed during the period 1997-2007, and matching these with variables from Experian, a private Danish data account register, we are able to identify the gender of the CEO and/or the chairman of the board of directors, the proportion of women on the board, and several other firm characteristics. This way, we can evaluate how gender of the CEO and composition of the board of directors (female chairman and share of women in the boardroom) are linked to both the level and the variability of firm economic outcomes over time measured as investment, profit, return to equity, and sales.

The findings in this study indicate that female-led companies are significantly different compared to maleled companies in the sense that having a female CEO is related to a lower variability in economic outcome variables as investments, profits, return on equity and sales. There are no systematic differences with respect to the relation between a female $\mathrm{CEO}$ and the absolute level of these variables. The gender of the chairman of the board of directors and the share of women in the boardroom seem to be much less correlated with level and variability of these firm outcome variables. In the few cases where significant coefficients appear for these variables, the sign of the coefficient is negative. The evidence that female-led firms present a more stable performance over time is indeed consistent with the hypothesis that women are more risk averse decision makers. These different attitudes towards risk are also in line with previous findings in the literature showing that women focus more than men on monitoring activities and on the implementation of a stricter firm governance.

Although our results cannot be considered causal effects of female-led companies, our study represents a first step towards a deeper and more rigorous analysis of how women in top managerial positions effectively can affect the risk profile of a firm. In fact, if confirmed by other scholars, the link between gender of CEO and volatility in firm outcomes may determine sensible consequences in terms of policy recommendations for private companies and of course provide further support or even strenghen the governmental action policies aimed at favoring gender equality among officers and other board members. 


\section{References}

[1] Adams, Susan M., Gupta, Atul, Leeth, John D., 2008. Are Female Executives Over-represented in Precarious Leadership Positions?. British Journal of Management 20(1), 1-12.

[2] Adams, Renee B., Ferreira, Daniel, 2009. Women in the boardroom and their impact on governance and performance. Journal of Financial Economics 94(2), 291-309.

[3] Angrist, Joshua D., and Pischke, Jörn-Steffen, 2009. Mostly harmless econometrics: An empiricist's companion. Princeton University Press.

[4] Bajtelsmit, Vickie L., VanDerhei, Jack L., 1997. Risk aversion and pension investment choices. In: Gordon, Michael S., Mitchell, Olivia S., Twinney, Marc M. (Eds.), Positioning Pensions for the TwentyFirst Century. University of Pennsylvania Press, Philadelphia, 45-66.

[5] Bertrand, Marianne, 2011. New Perspectives on Gender. Handbook of Labor Economics, chapter 17, vol. 4B. Amsterdam, The Netherlands: Elsevier B.V, 1545-92.

[6] Bilimoria, Diana, Piderit, Sandy K., 1994. Board committee membership: Effects of sex-based bias. Academy of Management Journal 37(6), 1453-1477.

[7] Bøhren, Øyvind, Strøm, R. Øystein, 2007. Aligned, informed, and decisive: Characteristics of valuecreating boards. EFA 2007 Ljubljana Meetings Paper, available at SSRN: http://ssrn. com/abstract. Vol. 966407.

[8] Carter, David A., Simkins, Betty J., and Simpson, W. Gary, 2003. Corporate governance, board diversity, and firm value. Financial Review 38(1), 33-53.

[9] Catalyst, 2003. Census of Women Board Directors. Catalyst, New York.

[10] Catalyst, 2007. Expanding Opportunities for Women and Business - Women in Management Global Comparison. Catalyst, New York.

[11] Croson, Rachel, Gneezy, Uri, 2009. Gender differences in preferences. Journal of Economic Literature $47(2), 1-27$.

[12] Dohmen, Thomas J., Falk, Armin, Huffman, David, Schupp, Juergen, Sunde, Uwe, Wagner, Gert G., 2011. Individual risk attitudes: measurement, determinants and behavioral consequences. Journal of the European Economic Association, 522-550. 
[13] Du Rietz, Anita, Henrekson, Magnus, 2000. Testing the female underperformance hypothesis. Small Business Economics 14(1), 1-10.

[14] Dwyer, Peggy D., Gilkeson, James H., List, John A., 2002. Gender differences in revealed risk taking: evidence from mutual fund investors. Economics Letters 76(2), 151-158.

[15] Eckel, Catherine C., Grossman, Philip J., 2002a. Sex differences and statistical stereotyping in attitudes toward financial risk. Evolution and Human Behavior 23(4), 281-295.

[16] Eckel, Catherine C., Grossman, Philip J., 2002b. Forecasting Risk Attitudes: An Experimental Study of Actual and Forecast Risk Attitudes of Women and Men. Unpublished manuscript, Department of Economics, Virginia Tech.

[17] Eckel, Catherine C., Grossman, Philip J., 2008. Sex and risk: experimental evidence. In: Plott, Charles, Smith, Vernon (Eds.), Handbook of Experimental Economics Results, vol. 1. Elsevier, New York.

[18] Erhardt, Niclas L., Werbel, James D., Shrader, Charles B., 2003. Board of director diversity and firm financial performance. Corporate Governance: An International Review 11(2), 102-111.

[19] Farrell, Kathleen A., Hersch, Philip L., 2005. Additions to corporate boards: The effect of gender. Journal of Corporate Finance 11(1), 85-106.

[20] Ferreira, Daniel, 2002. Essays on the economics of organizations. PhD Dissertation. Chicago: The University of Chicago, Department of Economics.

[21] Ferreira, Daniel, 2010. Board diversity. Corporate governance: a synthesis of theory, research and practice, 16 .

[22] Hartog, Joop, Ferrer-i-Carbonell, Ada, Jonker, Nicole, 2002. Linking measured risk aversion to individual characteristics. Kyklos 55(1), 3-26.

[23] Hillman, Amy J., Shropshire, Christine, Cannella, Albert A., 2007. Organizational predictors of women of corporate boards. Academy of Management Journal 50(4), 941-952.

[24] Jianakoplos, Nancy Ammon, Bernasek, Alexandra, 1998. Are women more risk averse? Economic Inquiry $36(4), 620-630$.

[25] Kesner, Idalene F., 1988. Directors' characteristics and committee membership: An investigation of type, occupation, tenure, and gender. Academy of Management Journal 31(1), 66-84. 
[26] Kochan, Thomas, Bezrukova, Katerina, Ely, Robin, Jackson, Susan, Joshi, Aparna, Jehn, Karen, Leonard, Jonathan, Levine, David, Thomas, David, 2003. The effects of diversity on business performance: Report of the diversity research network. Human Resource Management 42(1), 3-21.

[27] Levin, Irwin P., Snyder, Mary A., Chapman, Daniel P., 1988. The interaction of experiential and situational factors and gender in a simulated risky decision-making task. The Journal of Psychology 122 , $173-181$.

[28] Rose, Caspar, 2007. Does female board representation influence firm performance? The Danish evidence. Corporate Governance: An International Review 15(2), 404-413.

[29] Ryan, Michelle K., Haslam, S. Alexander, 2005. The glass cliff: Evidence that women are over-represented in precarious leadership positions. British Journal of Management 16(2), 81-90.

[30] Shrader, Charles. B., Blackburn, Virginia B., Iles, Paul, 1997. Women in management and firm financial performance: An exploratory study. Journal of Managerial Issues 9, 355-372.

[31] Smith, Nina, Smith, Valdemar, Verner, Mette, 2006. Do women in top management affect firm performance? A panel study of 2,500 Danish firms. International Journal of Productivity and Performance Management 55(7), 569-593.

[32] Smith, Nina, Smith, Valdemar, Verner, Mette, 2013. Why are so few females promoted into CEO and Vice-President positions? Danish empirical evidence 1997-2007, Industrial and Labor Relations Review, $66(2): 380-408$.

[33] Smith, Nina, 2013. Gender quotas on board of directors, IZA policy paper (forthcoming).

[34] Sunden, Annika E., Surette, Brian J., 1998. Gender differences in the allocation of assets in retirement savings plans. American Economic Review 88(2), 207-211.

[35] Terjesen, Siri, Sealy, Ruth, Singh, Val, 2009. Women directors on corporate boards: A review and research agenda. Corporate Governance: An International Review, 17(3), 320-337. 
Figure 1: Change in CEO gender and outcome variables in levels.
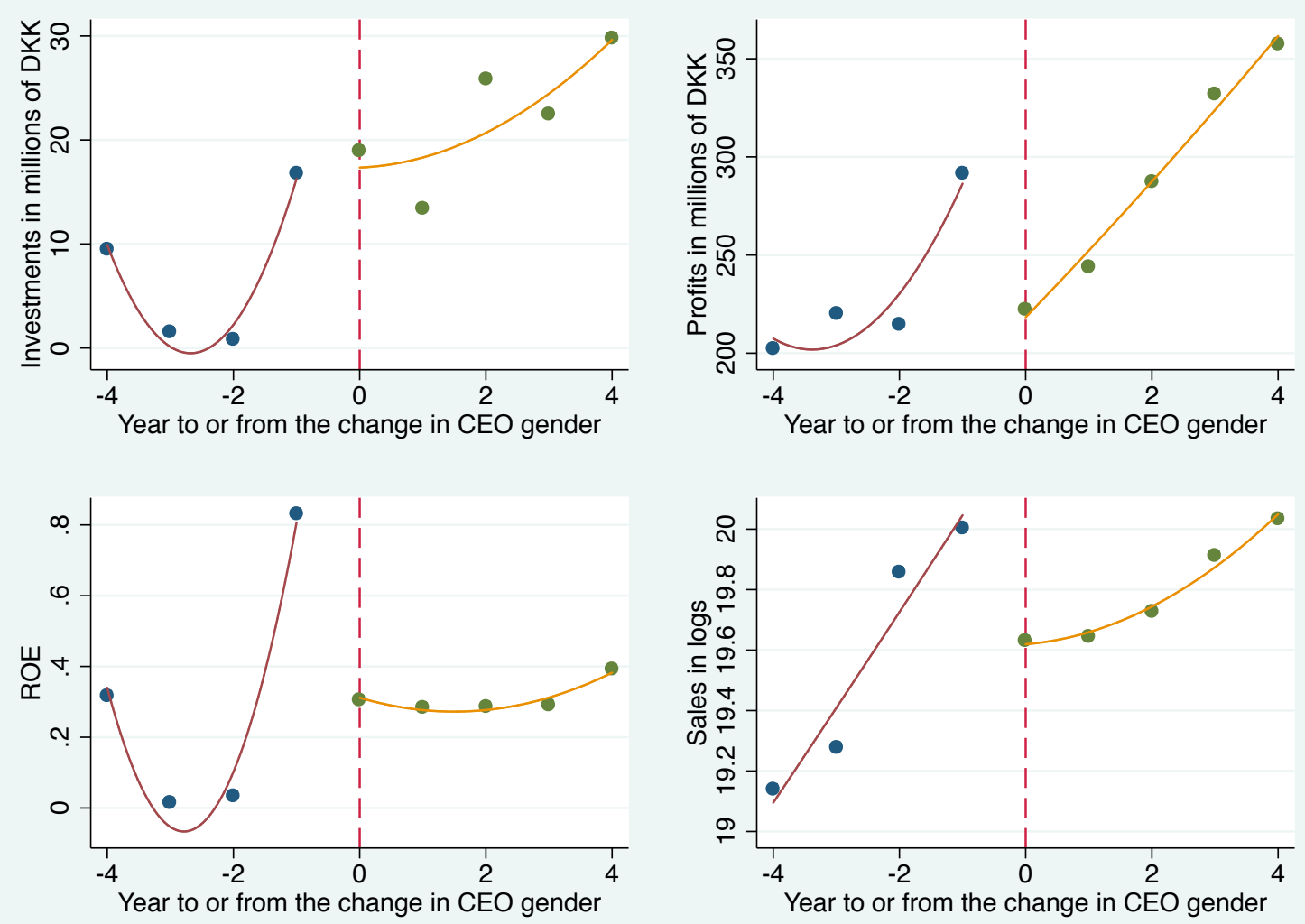

Source: Statistics Denmark.

Legend: Whereas dots are observed mean values, lines represent superimposed quadratic fits of dots. Dashed lines indicate the year of change in CEO gender (from male to female). 
Figure 2: Change in CEO gender and outcome variables in growth rates.
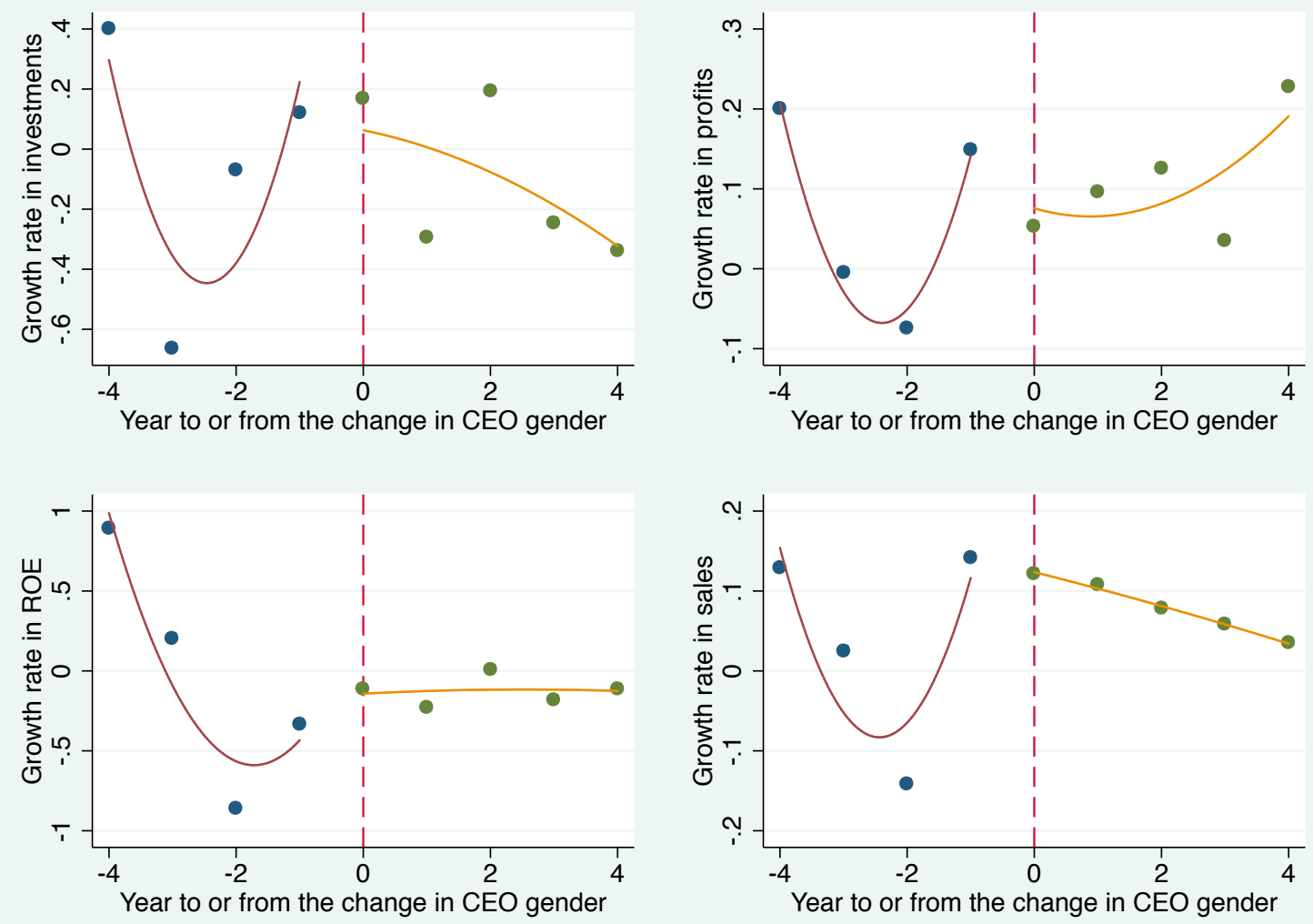

Source: Statistics Denmark.

Legend: Whereas dots are observed mean values, lines represent superimposed quadratic fits of dots. Dashed lines indicate the year of change in CEO gender (from male to female). 


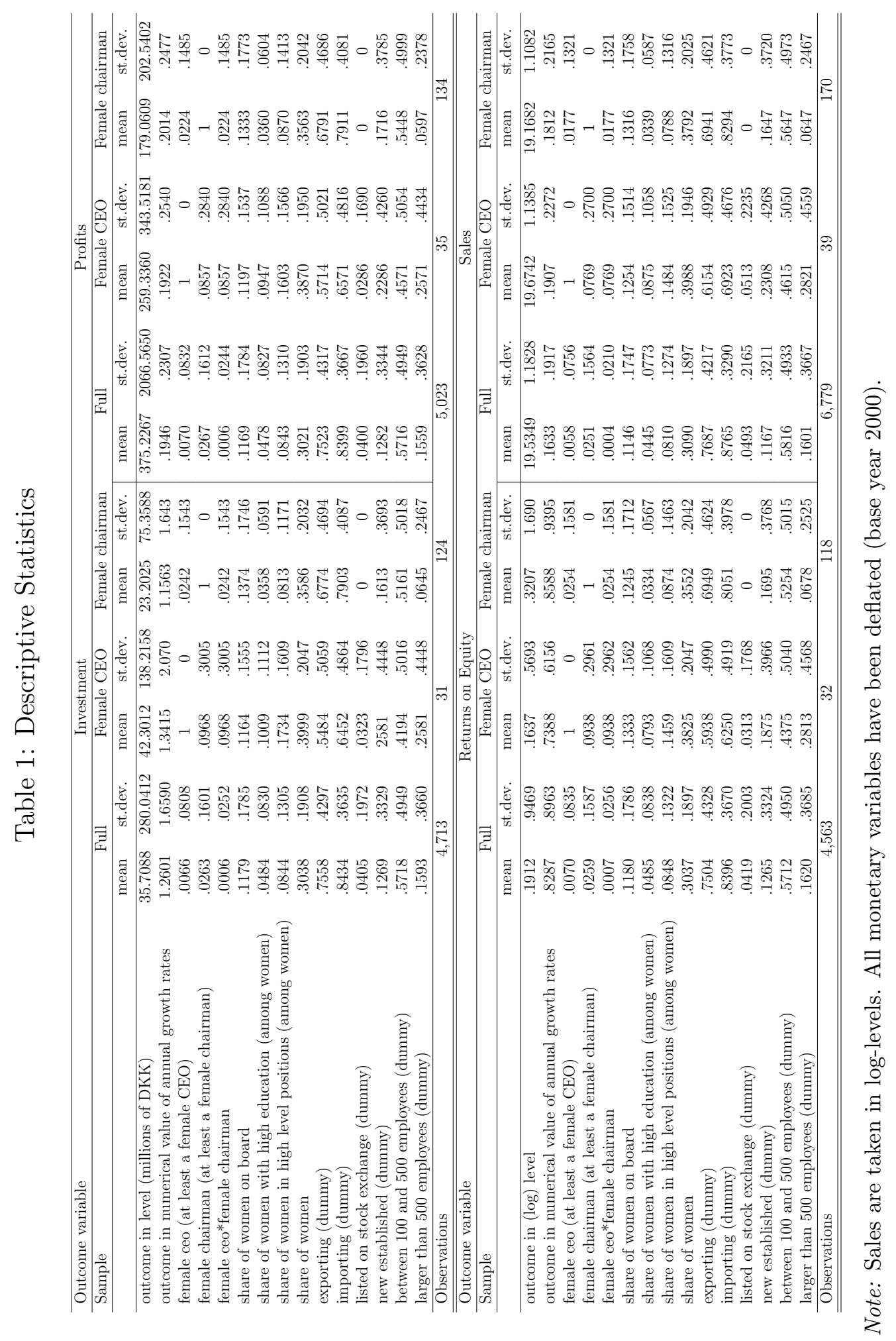




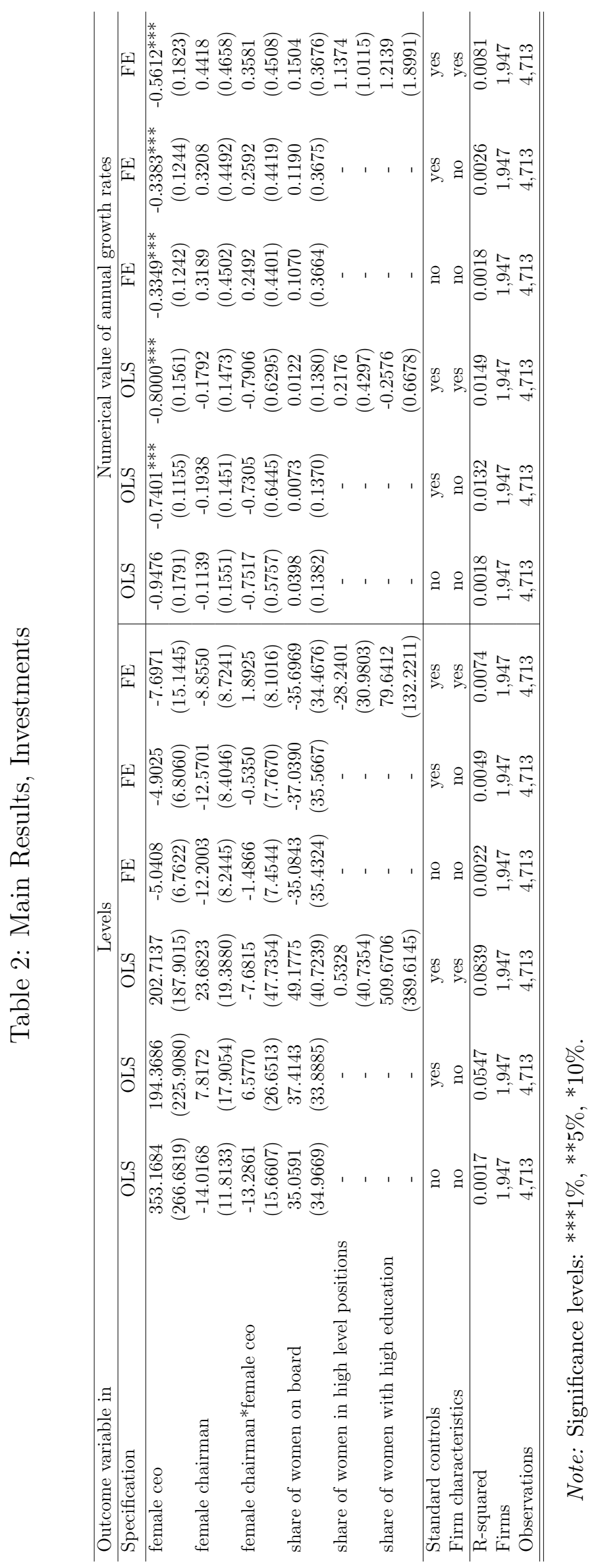




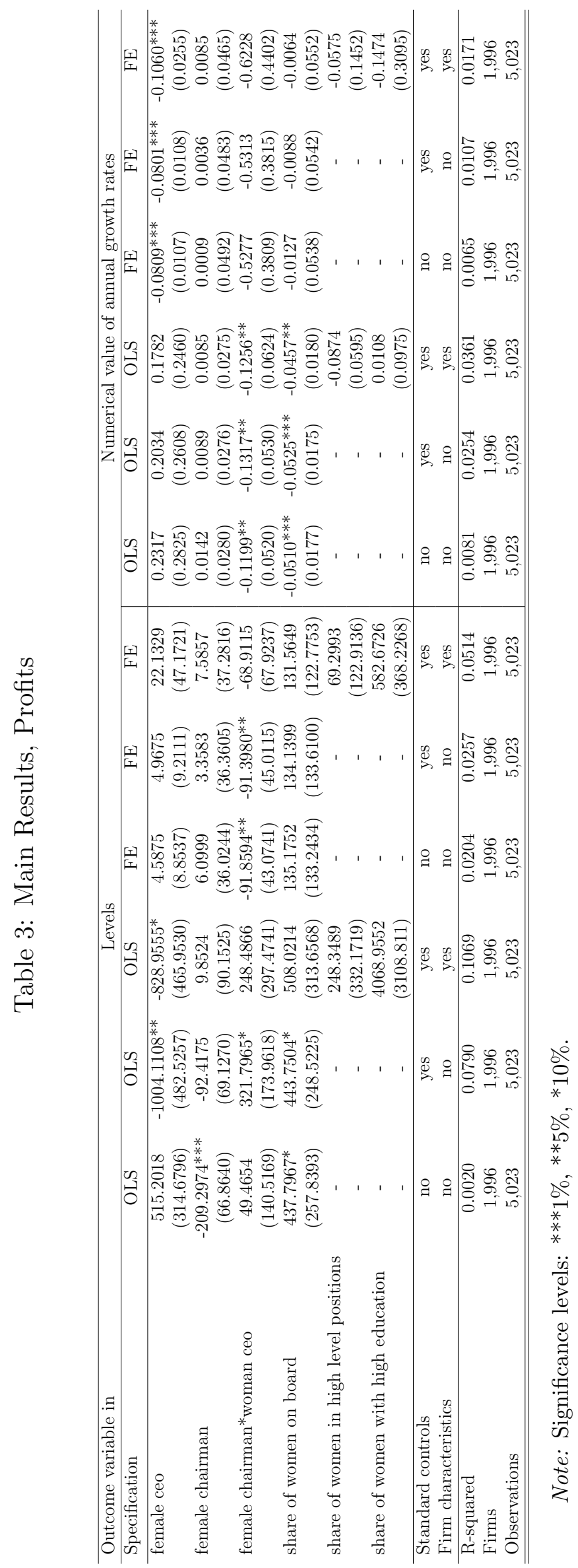




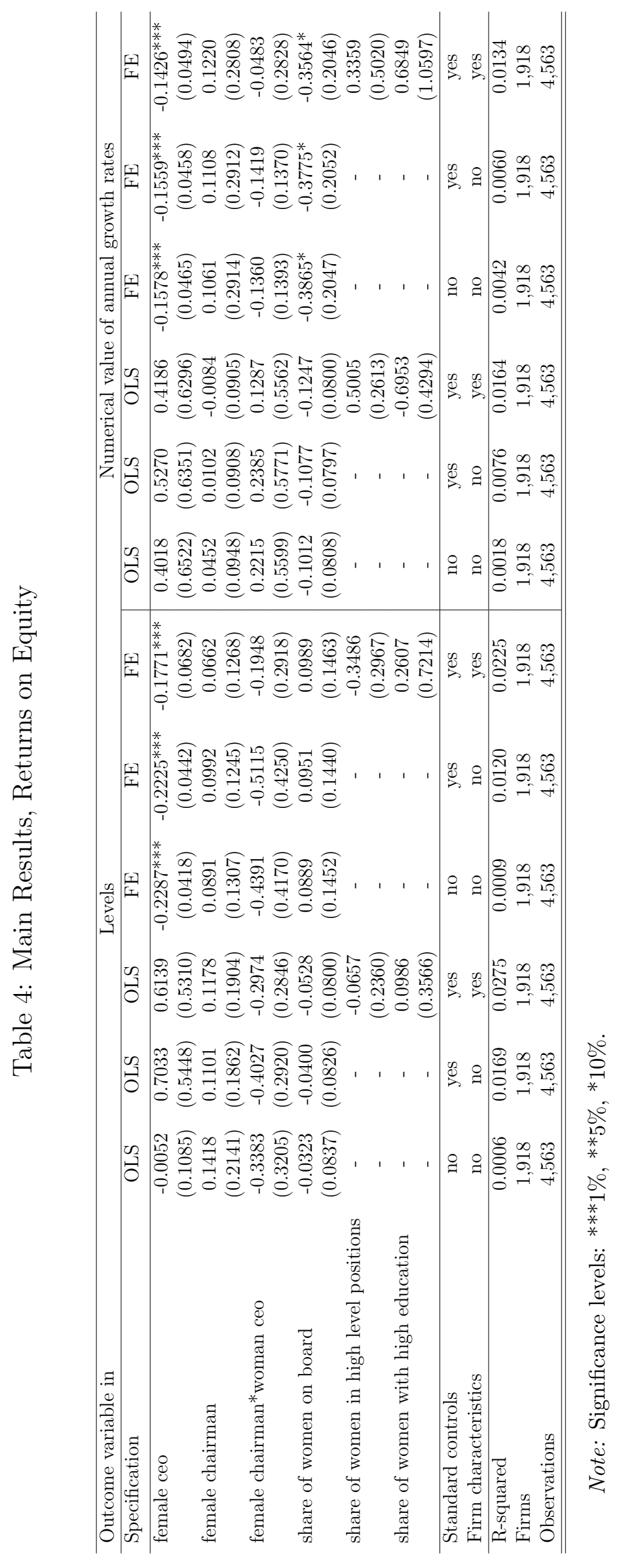




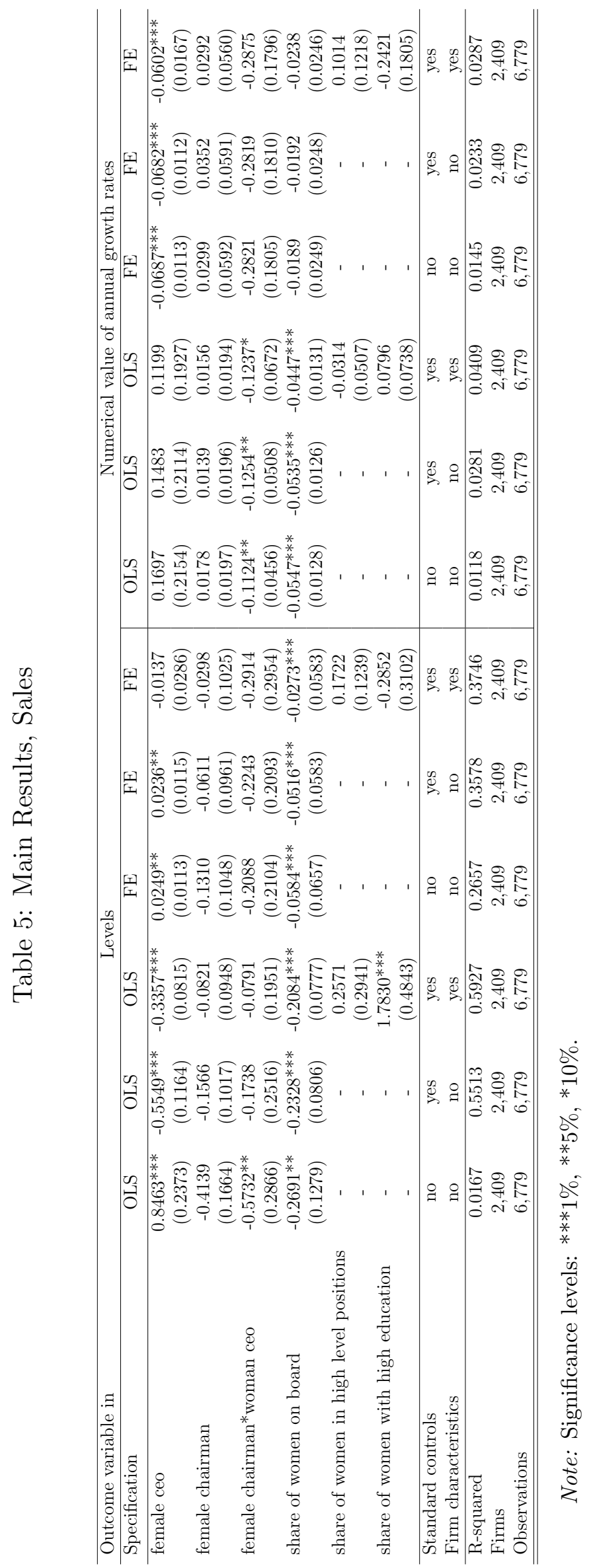


Table 6: Endogeneity Checks

\begin{tabular}{lccc|ccc}
\hline Numerical value of annual growth rates & \multicolumn{3}{c}{ Investments } & \multicolumn{3}{c}{ Profits } \\
\hline Specification & FE & FE & FE & FE & FE & FE \\
\hline F.female ceo & 0.3606 & 0.3720 & 0.4533 & -0.0217 & -0.0163 & -0.0170 \\
& $(0.4254)$ & $(0.4185)$ & $(0.4703)$ & $(0.0374)$ & $(0.0385)$ & $(0.0394)$ \\
F.female chairman & 0.1197 & 0.1349 & 0.2206 & -0.0071 & -0.0058 & 0.0079 \\
& $(0.4744)$ & $(0.4794)$ & $(0.4402)$ & $(0.0637)$ & $(0.0631)$ & $(0.0683)$ \\
F.female chairman*woman ceo & - & - & - & - & - & - \\
& - & - & - & - & - & - \\
F.share of women on board & -0.5781 & -0.5269 & -0.4954 & 0.0351 & 0.0327 & 0.0349 \\
& $(0.5062)$ & $(0.5133)$ & $(0.5129)$ & $(0.0672)$ & $(0.0651)$ & $(0.0688)$ \\
\hline Standard controls & no & yes & yes & no & yes & yes \\
Firm characteristics & no & no & yes & no & no & yes \\
\hline R-squared & 0.0035 & 0.0064 & 0.0177 & 0.0081 & 0.0148 & 0.0383 \\
Firms & 1,169 & 1,169 & 1,169 & 1,260 & 1,260 & 1,260 \\
Observations & 2,617 & 2,617 & 2,617 & 2,944 & 2,944 & 2,944 \\
\hline \hline Numerical value of annual growth rates & \multicolumn{2}{c}{ Returns on Equity } & \multicolumn{3}{c}{ Sales } & \\
\hline Specification & FE & FE & FE & FE & FE & FE \\
\hline F.female ceo & 0.9855 & 0.8910 & 0.7966 & -0.0364 & -0.0287 & -0.0322 \\
& $(0.9196$ & $(0.8363)$ & $(0.7617)$ & $(0.0492)$ & $(0.0481)$ & $(0.0480)$ \\
F.female chairman & 0.1143 & 0.0848 & 0.1242 & $-0.0549^{*}$ & -0.0437 & -0.0447 \\
& $(0.4995$ & $(0.5036)$ & $(0.5023)$ & $(0.0311)$ & $(0.0336)$ & $(0.0328)$ \\
F.female chairman*woman ceo & - & - & - & - & - & - \\
& - & - & - & - & - & - \\
F.female of women on board & 0.3657 & 0.3871 & 0.4220 & 0.0321 & 0.0315 & 0.0310 \\
& $(0.3201)$ & $(0.3173)$ & $(0.3134)$ & $(0.0321)$ & $(0.0315)$ & $(0.0310)$ \\
\hline Standard controls & no & yes & yes & no & yes & yes \\
Firm characteristics & no & no & yes & no & no & yes \\
\hline R-squared & 0.0065 & 0.0122 & 0.0187 & 0.0080 & 0.0161 & 0.0259 \\
Firms & 1,120 & 1,120 & 1,120 & 1,553 & 1,553 & 1,553 \\
Observations & 2,446 & 2,446 & 2,446 & 3,672 & 3,672 & 3,672 \\
\hline \hline
\end{tabular}

Note: Significance levels: ${ }^{* * *} 1 \%,{ }^{*} 5 \%,{ }^{*} 10 \%$. 


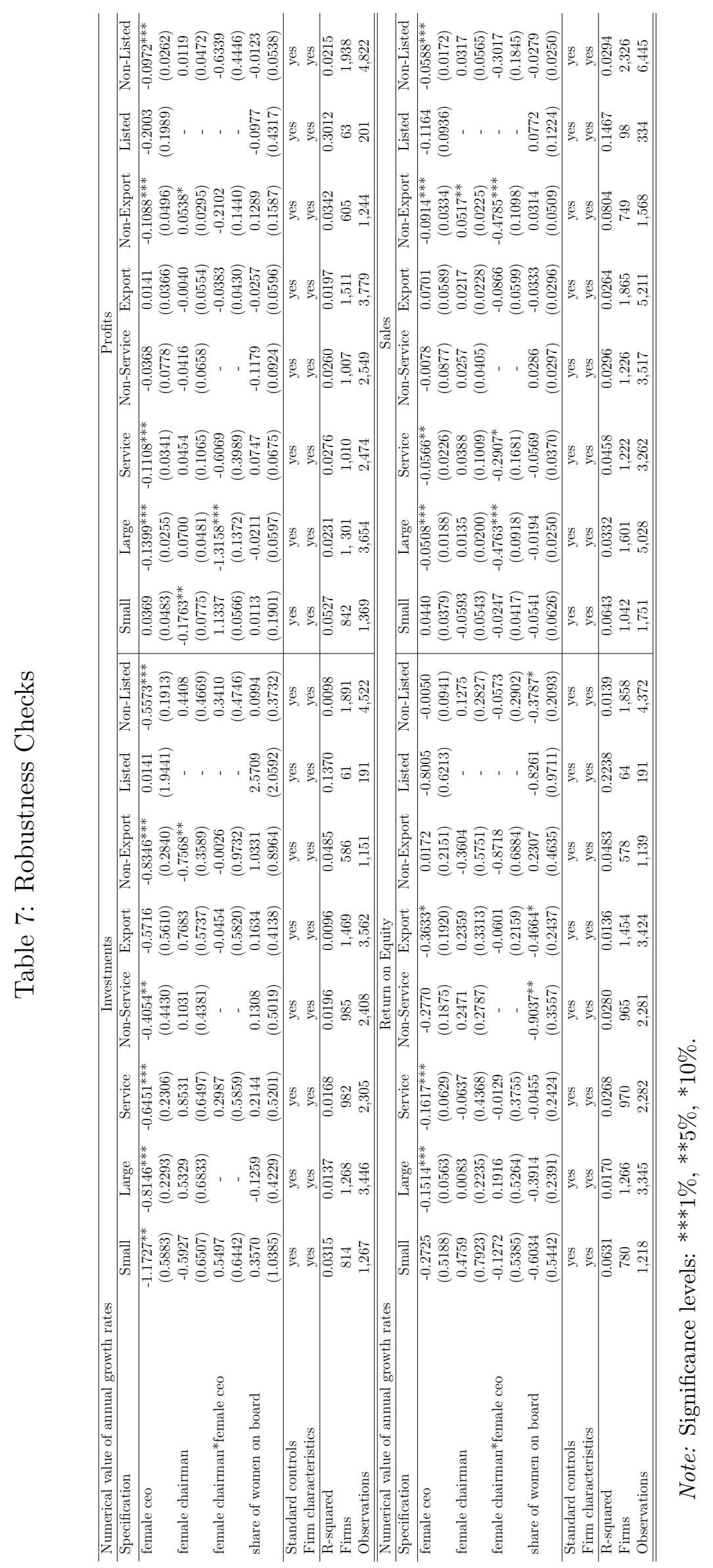

